\title{
Proceraea exoryxae sp. nov. (Annelida, Syllidae, Autolytinae), the first known polychaete miner tunneling into the tunic of an ascidian
}

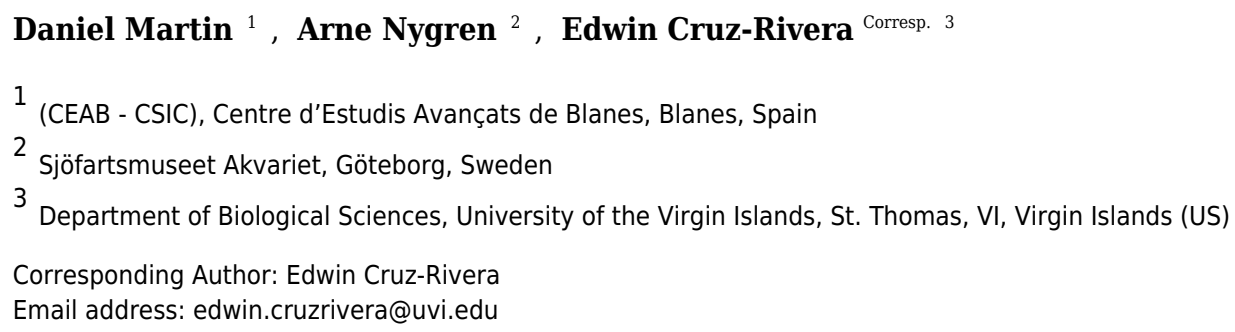

While studying organisms living in association with the solitary tunicate Phallusia nigra (Ascidiacea, Ascidiidae) from a shallow fringing reef at Zeytouna Beach (Egyptian Red Sea), one of the collected ascidians showed peculiar perforations on its tunic. Once dissected, the perforations revealed to be the openings of a network of galleries excavated in the inner tunic (atrium) by at least six individuals of a polychaetous annelid. The worms belonged to the Autolytinae (Syllidae), a subfamily that is well known to include specialized predators and/or symbionts, mostly associated with cnidarians. The Red Sea worms are here described as Proceraea exoryxae sp. nov., which are anatomically distinguished by the combination of simple chaetae only in anterior chaetigers, and a unique trepan with 33 teeth in one outer ring where one large tooth alternates with one medium-sized tricuspid tooth, and one inner ring with small teeth located just behind the large teeth. Male and female epitokes were found together with atokous individuals within galleries. Proceraea exoryxae sp. nov. constitutes the first known miner in the Autolytinae and the second species in this taxon known to live symbiotically with ascidians. The implications of finding this specialised parasite are discussed considering that $P$. nigra has been introduced worldwide, in tropical and sub-tropical ecosystems, where it has the potential of becoming invasive. 
1 Proceraea exoryxae sp. nov. (Annelida, Syllidae, Autolytinae), the first known

2 polychaete miner tunneling into the tunic of an ascidian

3 Daniel Martin $^{1}$, Arne Nygren $^{2}$ and Edwin Cruz-Rivera ${ }^{3 *}$

$4 \quad{ }^{1}$ Centre d'Estudis Avançats de Blanes (CEAB - CSIC), 17300 Blanes (Girona), Catalunya, Spain

$5 \quad{ }^{2}$ Sjöfartsmuseet Akvariet, Karl Johansgatan 1-3, 41459 Göteborg, Sweden

$6{ }^{3}$ Department of Biological Sciences, University of the Virgin Islands, \#2 John Brewers Bay, St. Thomas, Virgin

7 Islands 00802

$8 \quad *$ Corresponding author: edwin.cruzrivera@uvi.edu

\section{ABSTRACT}

10 While studying organisms living in association with the solitary tunicate Phallusia nigra (Ascidiacea, 11 Ascidiidae) from a shallow fringing reef at Zeytouna Beach (Egyptian Red Sea), one of the collected 12 ascidians showed peculiar perforations on its tunic. Once dissected, the perforations revealed to be the 13 openings of a network of galleries excavated in the inner tunic (atrium) by at least six individuals of a 14 polychaetous annelid. The worms belonged to the Autolytinae (Syllidae), a subfamily that is well known 15 to include specialized predators and/or symbionts, mostly associated with cnidarians. The Red Sea worms 16 are here described as Proceraea exoryxae sp. nov., which are anatomically distinguished by the 17 combination of simple chaetae only in anterior chaetigers, and a unique trepan with 33 teeth in one outer 18 ring where one large tooth alternates with one medium-sized tricuspid tooth, and one inner ring with small 19 teeth located just behind the large teeth. Male and female epitokes were found together with atokous 20 individuals within galleries. Proceraea exoryxae sp. nov. constitutes the first known miner in the 21 Autolytinae and the second species in this taxon known to live symbiotically with ascidians. The 22 implications of finding this specialised parasite are discussed considering that P. nigra has been introduced worldwide, in tropical and sub-tropical ecosystems, where it has the potential of becoming invasive. 
There are approximately 11,840 polychaete annelids known, spanning a remarkable array of habitats, ecological niches, and trophic modes (Read \& Fauchald 2016). Among these, symbiotic species (sensu Castro 2015) span at least 28 different families (Martin \& Britayev 1998). These symbiotic interactions, in general, are poorly understood, but cases of inquilinism, commensalism, mutualism and parasitism have been documented. Interestingly, parasitism seems to be among the least common modes of life for polychaetes $(<0.5 \%$ of known species, spread among 13 families), most of them being found within the Spionidae and most often being shell borers (Martin \& Britayev 1998). Several reports of associations with tunicates (Phylum Chordata) are available (Okada 1935; Spooner et al. 1957; Fiore \& Jutte 2010), but the polychaetes have not been identified in some of these instances (e.g., Illg 1958; Monniot 1990). been reported in one case (Spooner et al. 1957).

Phallusia nigra Savigny, 1816, is a solitary ascidian that has been introduced into tropical and subtropical ecosystems worldwide since it was originally discovered in the Red Sea (Shenkar 2012; Vandepas et al. 2015; Zhan et al. 2015). The ascidian hosts a remarkable array of crustacean symbionts, including amphipods and at least eight confirmed copepod species (Kim et al. 2016). During studies on the ecology of P. nigra and its associated fauna in the Egyptian coast of the Red Sea, one of the collected specimens showed various perforations on its tunic. Upon dissection, we discovered a network of excavated galleries resembling the habit of some leafmining herbivores in terrestrial and marine habitats (Brearley \& Walker 1995; Connor \& Taverner 1997; Sinclair \& Hughes 2010; Mejaes et al. 2015). The galleries were inhabited by several specimens of a small polychaete species belonging to the subfamily Autolytinae (Annelida, Syllidae). Although some bivalves and crustaceans have been reported to live within ascidian tunics (Lambert 2005; McClintock et al. 2009; Morton \& Dinesen 2011; Cañete \& Rocha 2013), no previous reports of annelids exhibiting a similar habit are known (Lambert 2005; Monniot 1990).

The Autolytinae are small free-living polychaetes, ranging from 1-60 mm long and from 0.1-1.2 mm wide. They are distributed worldwide and inhabit shallow waters, mostly restricted to the continental shelf. They often live in a more or less intimate association with sedentary invertebrates on which they supposedly feed, such as cnidarians (usually hydroids), but also bryozoans, sponges and tunicates (Okada 1928; Hamond 1969; Fauchald \& Jumars 1979; 
56 Genzano \& San Martín 2002; Nygren 2004; Nygren \& Pleijel 2007; Martin et al. 2015).

57 Autolytines are commonly found living inside thin, semi-hyaline tubes, either made in

58 association with the host or secreted by the worms and attached directly to the colonial animals

59 with which they associate (Gidholm 1967; Fischer et al. 1992; Genzano \& San Martín 2002).

60 Autolytinae constitute a phylogenetically well-delineated group of polychaetes in the

61 family Syllidae (Aguado \& San Martín 2009), characterized by a sinuous pharynx, absence of

62 ventral cirri, presence of simple bayonet-type dorsal chaetae, and reproduction with dimorphic

63 sexes (Franke 1999; Nygren \& Sundberg 2003; Nygren 2004). Since the comprehensive revision

64 by Nygren (2004), numerous new species have been described (Çinar \& Gambi 2005; Nygren \&

65 Pleijel 2007; Lucas et al. 2010; Nygren et al. 2010; Álvarez-Campos et al. 2014; Çinar 2015;

66 Dietrich et al. 2015; Martin et al. 2015; Aguirre et al. 2016). Currently, the subfamily comprises

67180 nominal species, of which 112 are considered valid and distributed among 13 recognized

68 genera (Nygren \& Pleijel 2007; Nygren et al. 2010; Rivolta et al. 2016). Among them, Proceraea

69 Ehlers, 1864 contains 28 species (Nygren 2004; Nygren et al. 2010; Martin et al. 2015).

70 It is in Proceraea that we place the new species herein described, which occurs inside 71 galleries excavated in the tunic of P. nigra and is, thus, the first known miner autolytine. This

72 finding led us to discuss the current knowledge on symbioses involving autolytines, as well as the

73 possible ecological implications of the symbiotic relationship between the polychaete and its host 74 ascidian. 


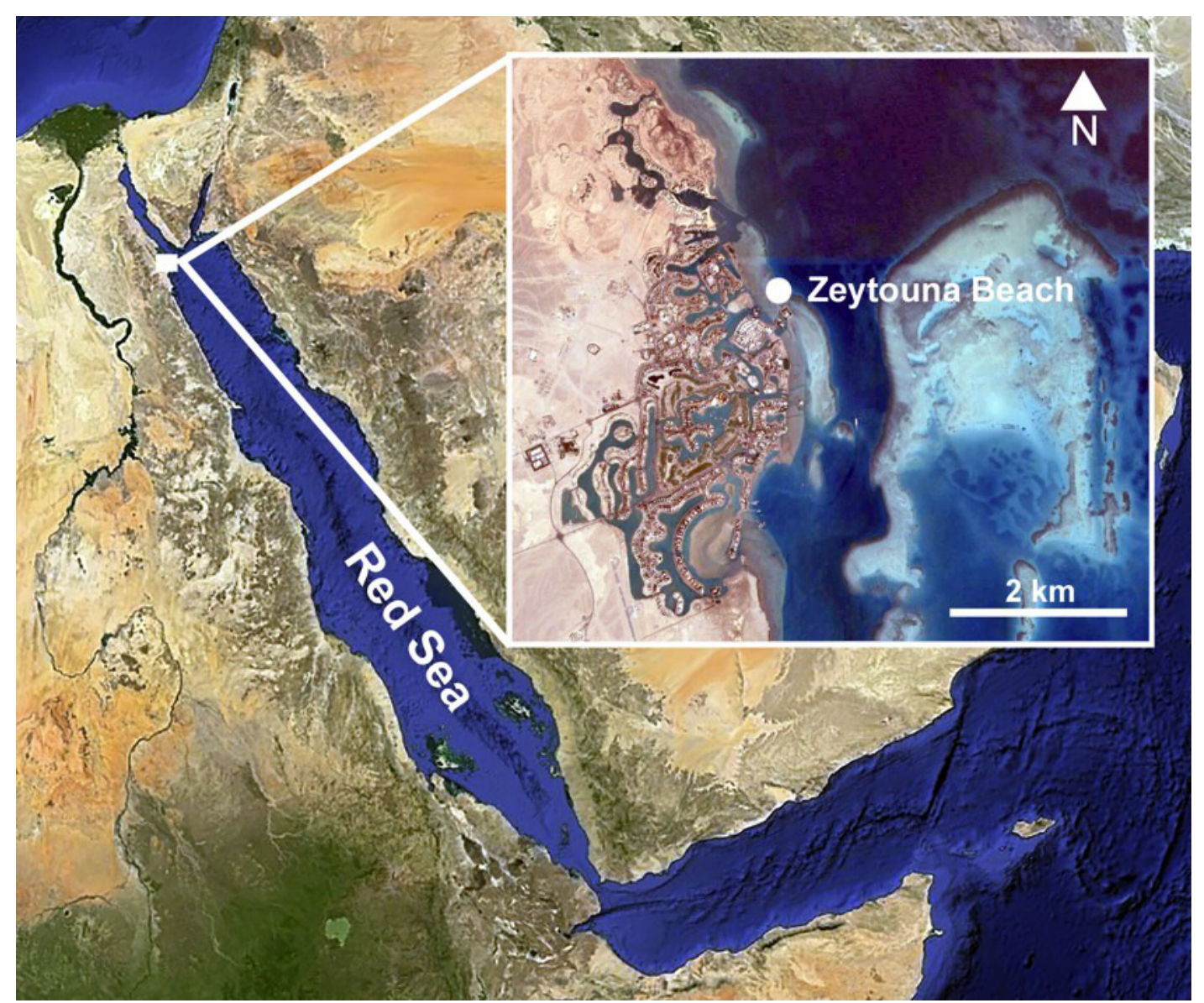

75 Figure 1. Location of the sampling site. Zeytouna Beach, Egyptian coast of the Red Sea. Maps

76 are from Google Earth Pro, (C) 2016 DigitalGlobe, (C) 2016 CNS / Astrium.

\section{MATERIAL AND METHODS}

78 Individuals of Phallusia nigra were collected by SCUBA from the shallow fringing reef at 79 Zeytouna Beach, on the Egyptian Red Sea $\left(27^{\circ} 24^{\prime} 09.2^{\prime \prime} \mathrm{N} 33^{\circ} 41^{\prime} 08.5^{\prime \prime E}\right.$; Fig. 1) under the 80 auspices of the John D. Gerhart Field Station in El Gouna (American University in Cairo), with 81 permission from the management of Zeytouna Beach. All ascidians were collected on October 7, $82 \quad 2010$ at 3-7 m depth and brought to the El Gouna Field Station. In the laboratory, the specimens 83 of $P$. nigra $(\mathrm{N}=50)$ were dissected with an incision around the entire periphery of the tunic, and 84 the visceral mass and the pharyngeal sac were removed (Fig. 2A). All of them were inspected for 85 associated animals. Ascidian masses and any abnormalities or damage on the hosts were 86 recorded. Dissected hosts and symbionts from the atrial cavity were photographed with a digital 87 camera equipped with a macro lens. 


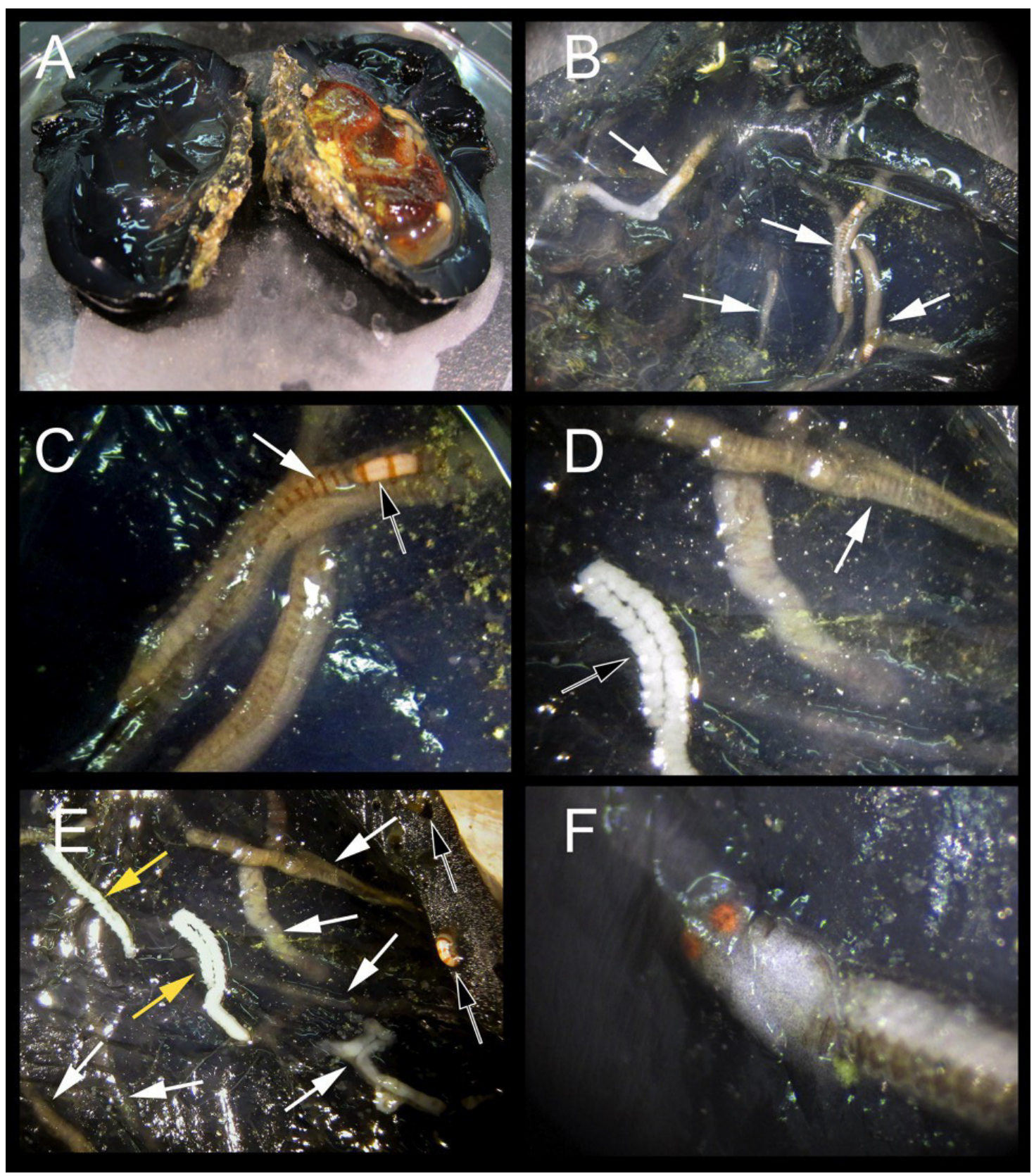

88 Figure 2. Host dissection and location of mining polychaetes. (A) An uninfected Phallusia

89 nigra dissected to show normal atrial surface (left) and internal organs. (B) Inner atrial surface

90 showing the presence of several atokous forms inside their galleries (white arrows). (C) Detail of

91 the colour of the anterior region of an atokous form; white arrow: position of pharynx; black

92 arrow: position of proventricle. (D) Detail of colour of the mid-body of an atokous form (white

93 arrow) and the posterior region of a male epitokous form (black arrow). (E) Inner atrial surface

94 showing the presence of atokous (white arrows) and male epitokous (yellow arrows) forms inside

95 their galleries, as well as part of the banded body of an atokous form protruding from an external

96 tunic opening and other empty tunic openings (black arrows). (F) Close-up view of the head of a

97 male epitoke in its gallery (specimen not preserved). 
The entire tunic of the infested ascidian specimen was placed in formaldehyde for a few

99

100

101

102

103

104

105

106

107

108

109

110

111 seconds. Then, the galleries were cut with an angular-tipped scalpel through the atrial surface of the tunic to extract mining autolytines with the help of fine forceps. However, their body was very delicate and all of them broke during extraction. In fact, some stolons were completely destroyed in the process and it was not possible to save them for taxonomic studies. All obtained specimens were fixed and preserved in a $4 \%$ formalin-seawater solution and transferred to $70 \%$ ethanol prior to observations.

Light microscope photos were taken with a Canon EOS 5D Mark II connected to either a Zeiss KF2 triocular microscope via a LM-Scope TUST42C coupler, or a Canon EF 65mm macro lens with 1-5 times magnification. For Scanning Electron Microscope (SEM) observations, the $70 \%$ ethanol preserved materials were prepared using standard SEM procedures (Martin et al. 2003). Prior to run the SEM procedures to observe the trepan, this structure was carefully dissected and as much as possible cleaned from the external muscular tissue layer. Images were taken in a Hitachi TM3000 TABLETOP microscope at the SEM service of the CEAB - CSIC.

The electronic version of this article in Portable Document Format (PDF) will represent a published work according to the International Commission on Zoological Nomenclature (ICZN), and hence the new names contained in the electronic version are effectively published under that Code from the electronic edition alone. This published work and the nomenclatural acts it contains have been registered in ZooBank, the online registration system for the ICZN. The ZooBank LSIDs (Life Science Identifiers) can be resolved and the associated information viewed through any standard web browser by appending the LSID to the prefix http://zoobank.org/. The LSID for this publication is: urn:lsid:zoobank.org:pub:685CB1C2-CB5B-4A87-9CD7C04BFFDE03B4. The online version of this work is archived and available from the following digital repositories: PeerJ, PubMed Central and CLOCKSS. Specimen vouchers were deposited at the Museo Nacional de Ciencias Naturales of Madrid, Spain (MNCN).

\section{RESULTS}

\section{Taxonomic account}

Phylum ANNELIDA Lamarck, 1809

Subclass ERRANTIA Audouin \& Milne-Edwards, 1832 
127

128

129

130

131

132

133

134

135

Order PHYLLODOCIDA Dales, 1962

Suborder NEREIDIFORMIA

Family SYLLIDAE Grube, 1850

Subfamily AUTOLYTINAE Langerhans, 1879

Tribe PROCERINI Nygren, 2004

Genus Proceraea Ehlers, 1864

\section{Proceraea exoryxae sp. nov.}

LSID. urn:1sid:zoobank.org:act:34373CE6-A0D4-488D-B4A5-12CF4E103504

(Figures 2-7)

Type material. Holotype. MNCN 16.01/17717: atokous anterior fragment, Zeytouna Beach, Egyptian Red Sea, 27²4'09.2"N 3341'08.5"E, October 7 2010, 3-7 m depth, E. Cruz-Rivera coll.; fixed in 4\% formalin seawater, preserved in 70\% ethanol. Paratypes. MNCN 16.01/17718: atokous anterior fragment, pharynx dissected; $\mathrm{MNCN}$ 16.01/17719: atokous specimen, anterior fragment (up to chaetiger 10) prepared for SEM, mid-body segments and dissected proventricle preserved in 70\% ethanol; MNCN 16.01/17720: atokous anterior fragment, pharynx dissected; MNCN 16.01/17721: male stolon, anterior fragment; MNCN 16.01/17722: female stolon, anterior fragment; MNCN 16.01/17723: atokous mid-body fragments. MNCN 16.01/17724: atokous posterior fragments. Collection details for all other types deposited are the same as for holotype.

Diagnosis. Proceraea with simple chaetae in anterior chaetigers, and a trepan with 33 teeth with one outer ring where one large tooth alternates with one medium-sized tricuspid tooth, and one inner ring with small teeth located just behind the large teeth.

Description. All observations are from preserved specimens if not otherwise stated. Length 3$10.5 \mathrm{~mm}$ for 10-68 chaetigers in four anterior fragments, 3-14.5 mm for 19-90 chaetigers in nine median fragments, and 6.5-22 $\mathrm{mm}$ for 50-125 chaetigers in three posterior fragments. Width of anterior fragments, excluding parapodial lobes, c. $0.4 \mathrm{~mm}$. Live individuals dorsally with light brown transverse stripes, one per segment, not known whether these are inter- or intrasegmental, or if there is any other additional coloration (Fig. 2B-E); proventricle white (Fig. 2B, C). Formalin preserved specimens without any sign of coloration. 
156 Body shape, excluding parapodial lobes, cylindrical in transection, ventrally flattened. 157 Body long and slender, with slowly tapering end. Nuchal organs ciliated. Prostomium rounded 158 rectangular (Fig. 3A, C). Four eyes with lenses, anterior pair larger, confluent in dorsal view, eye 159 spots absent (Fig 3C). Palps in dorsal view projecting c. half of prostomial length, fused (Fig. 3A, 160 B). 

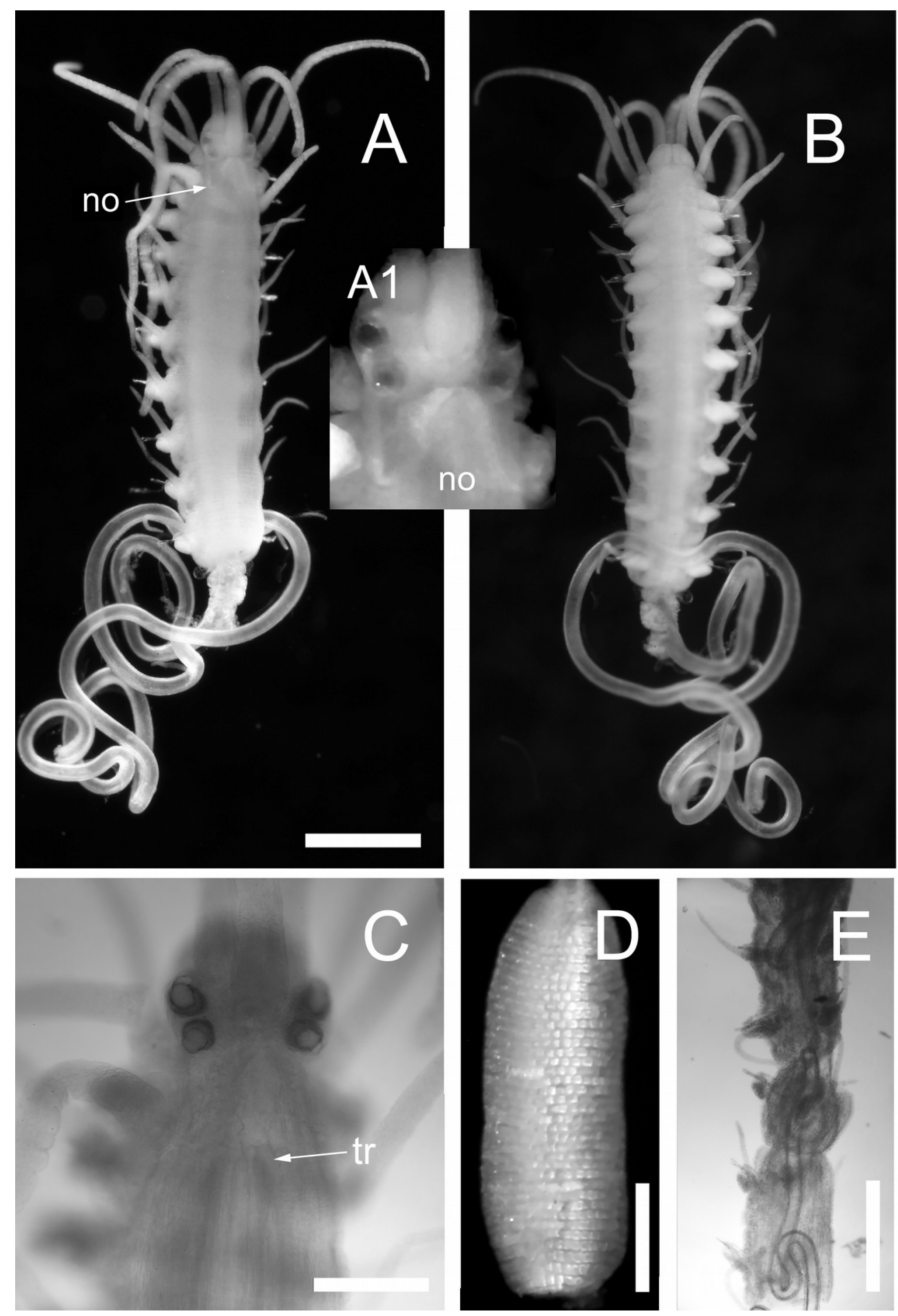

161 Figure 3. Proceraea exoryxae sp. nov. (A) Anterior fragment, dorsal view [MNCN 162 16.01/17719], and detail of the head from the same specimen (A1). (B) Anterior fragment, ventral 163 view [MNCN 16.01/17719]. Body is broken after chaetiger 10, exposing the pharynx (A and B). 164 (C) Anterior end, dorsal view [MNCN 16.01/17719]. (D) Proventricle [MNCN 16.01/17719]. (E) 165 Pharynx sinuation in chaetigers 9-14, dorsal view [MNCN 16.01/17720]. Abbreviations as 166 follows: $\mathrm{no}=$ nuchal organs, $\mathrm{tr}=$ position of trepan. Scale bars $\mathrm{A}, \mathrm{B}, \mathrm{E}=0.5 \mathrm{~mm}, \mathrm{C}, \mathrm{D}=0.2 \mathrm{~mm}$. 
Nuchal organs extending to median part of chaetiger 1 (Fig. 3A, A1). Prostomium with three antennae, median antenna inserted medially on prostomium, lateral antennae on anterior margin. Median antenna reaching chaetiger 8-10, lateral antennae about half as long as median antenna. Tentacular cirri two pairs. Dorsal tentacular cirri about two third as long as median antenna, ventral tentacular cirri about half as long as dorsal tentacular cirri. First dorsal cirri about as long as median antenna, second dorsal cirri as long as ventral tentacular cirri. From chaetiger 3 to chaetiger 20-25, cirri alternate indistinctly in length, shorter cirri slightly shorter and longer cirri equal or slightly longer than body width excluding parapodial lobes (Fig. 3A, B), dorsal cirri in more posterior chaetigers more or less equal in length, c. half of body width excluding parapodial lobes; anal cirri as long as half body width, excluding parapodial lobes at level of proventricle.

Cirrophores on tentacular cirri, first and second dorsal cirri (Fig. 3A), otherwise absent. Antennae, tentacular cirri, dorsal cirri, and anal cirri cylindrical. Parapodial lobes rounded. Aciculae 2-3 in anterior chaetigers, 1-2 in median and posterior chaetigers, straight, with a round, swollen distal end (Fig. 4G).

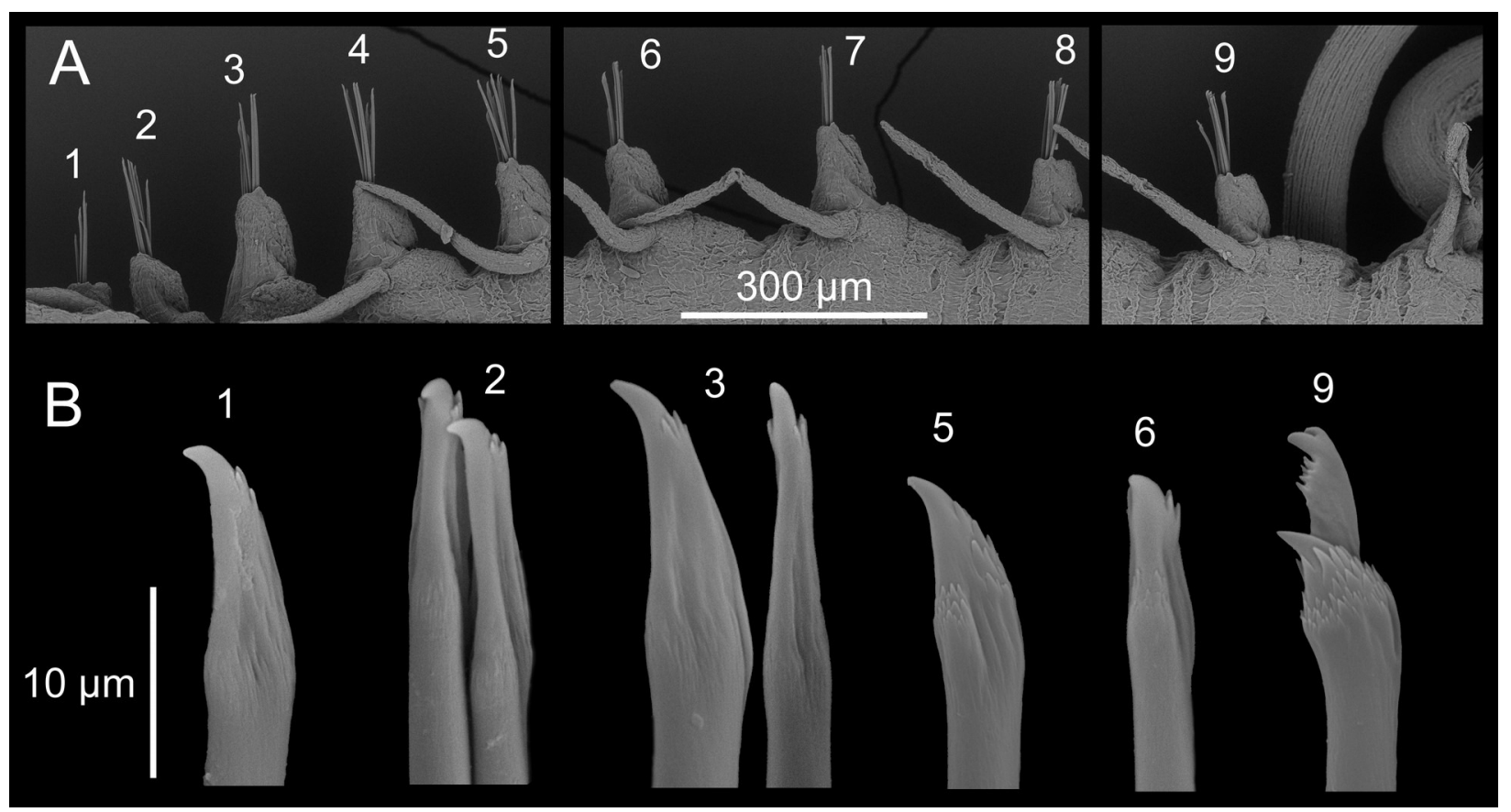
the swollen neck from chaetigers 1 to $3 ; 5-6$, simple chaetae with short region distal to the swollen neck from chaetigers 5 and 6;9, compound chaetae from chaetiger 9. 
187 Chaetal fascicle with 9-12 chaetae in anterior chaetigers (Fig. 4A), 4-10 in median and 188 posterior chaetigers. Chaetiger 1-5 with simple chaetae only (Fig. 4B, 5A-D), chaetiger 6 with 189 simple chaetae only $(n=3)$, or with single compound chaeta in addition to the simple chaetae $190(\mathrm{n}=1)$. From chaetiger 7 to between chaetiger 10-13 with an increasing proportion of compound 191 chaetae (Fig. 4A). Except for the single, thick, distally denticulated bayonet chaeta (Fig. 5E), 192 starting at the earliest in chaetiger 9, more posterior chaetigers with compound chaetae only. 193 Simple chaetae unidentate with rows of spines subdistally (Fig. 4B, 5A-D, F). In anterior 4-5 194 chaetigers most simple chaetae with a proportionally long region distal to the swollen neck (Fig. 195 4B, 5B-D), one or two of the inferior-most chaetae with a shorter region distal to the swollen 196 neck (Fig. 4B, 5A, C, D), similar in appearance to the shafts of the compound chaetae found in 197 later chaetigers. Starting from chaetigers 6-7 all simple chaetae (except for the bayonet chaeta) 198 nearly identical to the shafts of the compound chaetae (Fig. 4B, 5E). Blades of compound chaetae serrated, with two large distal teeth, distal-most slightly smaller, becoming smaller to almost disappear in mid-body and posterior chaetigers, shafts with a swollen neck with rows of spines 201 (Fig. 4B, 5E). 

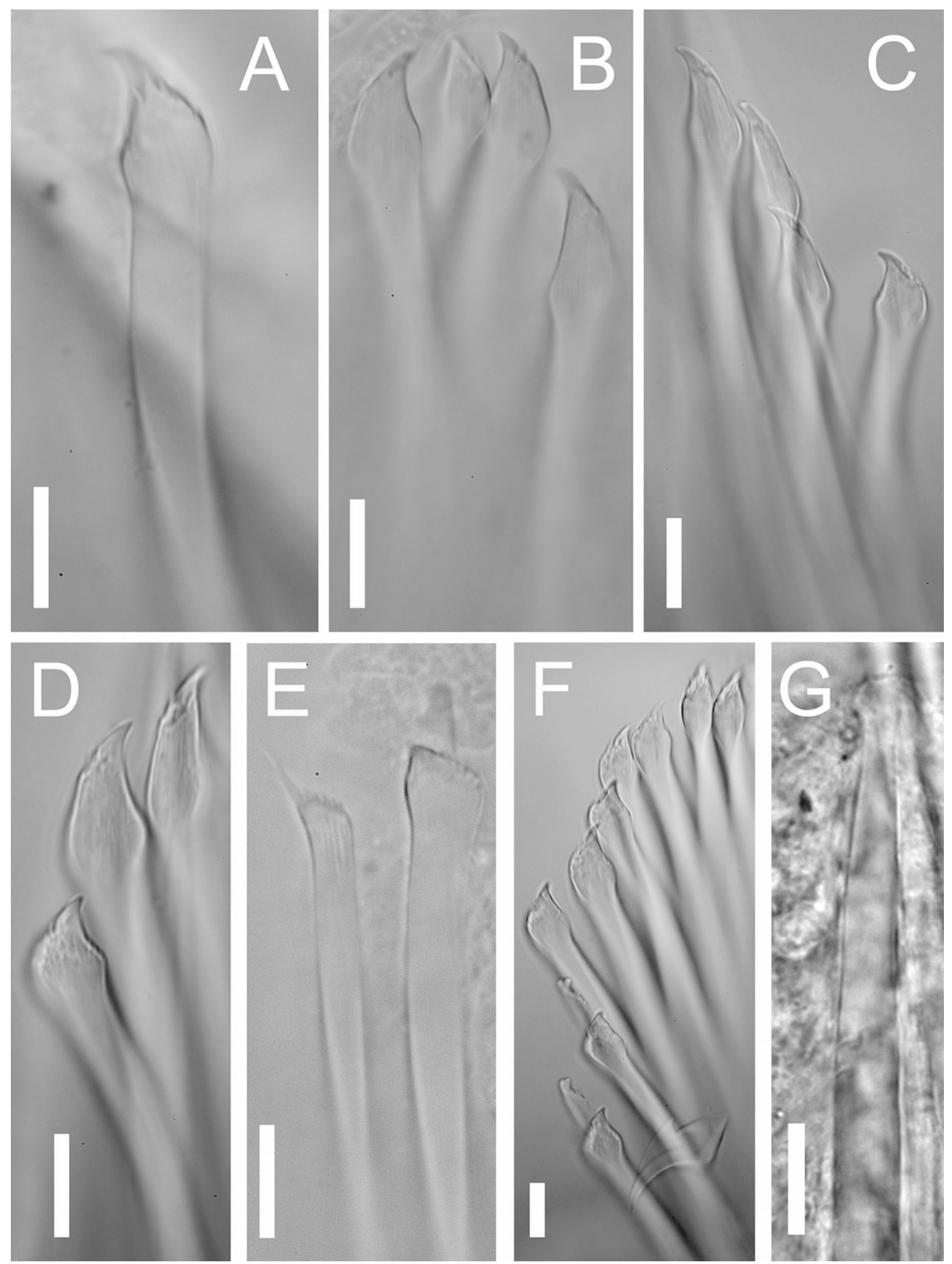

Figure 5. Proceraea exoryxae sp. nov.morphology of chaetae and aciculae. (A) Inferior-most simple chaeta, chaetiger 1 [MNCN 16.01/17717]. (B) Simple chaetae, chaetiger 3 [MNCN 16.01/17717]. (C) Simple chaetae, chaetiger 4 [MNCN 16.01/17719]. (D) Simple chaetae, 205 chaetiger 5 [MNCN 16.01/17719]. (E) Simple and compound chaetae, chaetiger 10 [MNCN 206 16.01/17719]. (F) Bayonet chaeta and compound chaeta, chaetiger 9 [MNCN 16.01/17717]. (G) Mid-body acicula [MNCN 16.01/17723]. Scale bars A-G $=0.1 \mathrm{~mm}$. 
210 outer ring where one large tooth alternates with one medium-sized tricuspid tooth, and one inner

211 ring with small teeth located just behind the large teeth. (Fig. 6A, B, C). Basal ring present, 212 infradental spines absent. Proventricle as long as three segments in chaetiger 20-22 (uncertain 213 observation, as the single specimen with proventricle still inside body looks distorted in this 214 region), with 40-45 rows of square-shaped muscle cells ( $\mathrm{n}=2)$ (Fig. 2C, 3D).

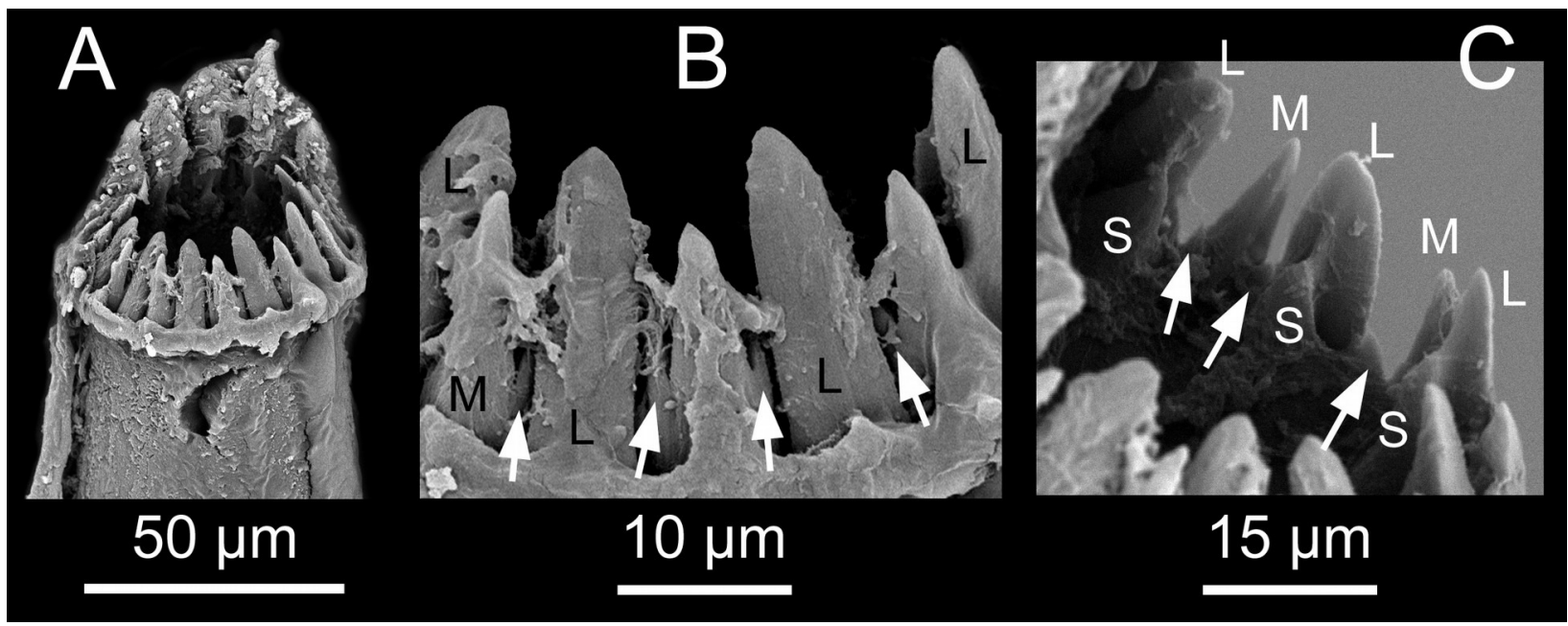

215 Figure 6. Proceraea exoryxae sp. nov.SEM micrographs of trepan structure. (A) Whole view 216 of the trepan (teeth on the back partly covered by tissue) [MNCN 16.01/17720]. (B) Large and 217 medium, tricuspid teeth in external view. (C) Large, medium, tricuspid and small teeth in internal 218 view. L: Large teeth; M: Medium, tricuspid teeth; S: small teeth; white arrows pointing on the 219 lateral cusps.

Distribution. Known only from the type locality, Zeytouna Beach (Egyptian coast of the Red 221 Sea).

222 Etymology. The specific epithet "exoryxae" derives from the term $\varepsilon \xi$ ó $\rho v \xi \eta$, which means miner 223 in Greek.

Ecology. Proceraea exoryxae sp. nov. was extremely rare. It was only found in one P. nigra specimen, despite multiple successive collections of this ascidian in the same and other reefs during following years (Kim et al. 2016). The excavated galleries in which the new autolytine resided were visible only through the atrium wall (the internal surface of the tunic; Fig. 2B-F), whereas the outside surface of the host tunic showed no signs of deformation, aside from the entrance openings of the galleries (Fig. 2E). The inner walls of the galleries were covered by a 
230 thin hyaline layer, apparently secreted by the worms. The wet mass of the individuals of P. nigra

231 collected in this reef ranged from 7.32 to $13.25 \mathrm{~g}$ and the specimen containing P. exoryxae sp.

232 nov. was $11.10 \mathrm{~g}$. Two individuals of the amphipod Leucothoe furina (Savigny, 1816), a common

233 associate of Phallusia nigra in the Egyptian Red Sea (White 2011) were also found in the same 234 host.

\section{Reproduction}

236

Probably with schizogamy, as several male and female stolons where found in the same galleries as the atokous forms (Fig. 2 D-F). Stolons were obtained detached from the corresponding stocks. However, they have bayonet and compound chaetae identical to those in the atokous forms, thus strengthening the hypothesis that they belong to P. exoryxae sp. nov. Male and female stolons are described below.

Morphology of the epitokous male. Length $2.7 \mathrm{~mm}$ for $6+17$ chaetigers in region a and $\mathrm{b}$ (see Nygren 2004), incomplete; width in region a $0.4 \mathrm{~mm}$ excluding parapodial lobes, in region b 0.7 $\mathrm{mm}$ including parapodial lobes. Exact colour in vivo unknown, but either the ventral or the dorsal side of region $\mathrm{b}$ dark brownish, region a whitish, with diffuse darker pigmentation (Fig. 2F). Preserved specimen whitish, without colour markings, chaetiger 2-6 with paired yellowish sperm glands seen through the body wall (Fig. 7B). Prostomium rounded rectangular, wider than long, anterior margin convex. Four eyes with lenses, situated ventro-lateral and dorsal on prostomium, ventro-lateral pair larger (Fig. 7A, B). Palps absent. Nuchal organs not seen. Median antenna inserted medially on prostomium, reaching c. chaetiger 10; lateral bifid antennae, inserted on anterior margin, equal in length to prostomial width; basal part 1/3 of total length, outer ventral rami slightly longer and thinner than inner dorsal rami. Frontal processes possibly absent, or developing (seen as small protuberances on prostomium lateral to the median antenna) (Fig. 7A). Tentacular cirri 2 pairs (Fig. 7B), dorsal tentacular cirri, as long as $1 / 2$ prostomial width, ventral tentacular cirri, 1/3 as long as dorsal pair. First dorsal cirri, equal in length to median antenna. Achaetous knobs absent. Cirri in region a reciprocally equal, equal in length to $1 / 2$ body width excluding parapodial lobes, cirri in region $b$ reciprocally equal, slightly shorter than cirri in region a. Short median ceratophore, and short cirrophores on first dorsal cirri, cirrophores otherwise absent. Median antenna, tentacular cirri, first dorsal cirri, and cirri in region a and $\mathrm{b}$ cylindrical. Parapodia in region a uniramous, neuropodial lobes rounded, parapodia in region $b$ 
260 with developing notopodial lobes. Single neuropodial acicula in all chaetigers; 2 anterodorsal and

2615 posteroventral notopodial aciculae in region b. Neuropodial fascicle with 7-8 compound 262 chaetae and a single bayonet chaeta of the same types described for the atoke. Swimming chaetae 263 absent, indicating a non fully-developed male stolon.
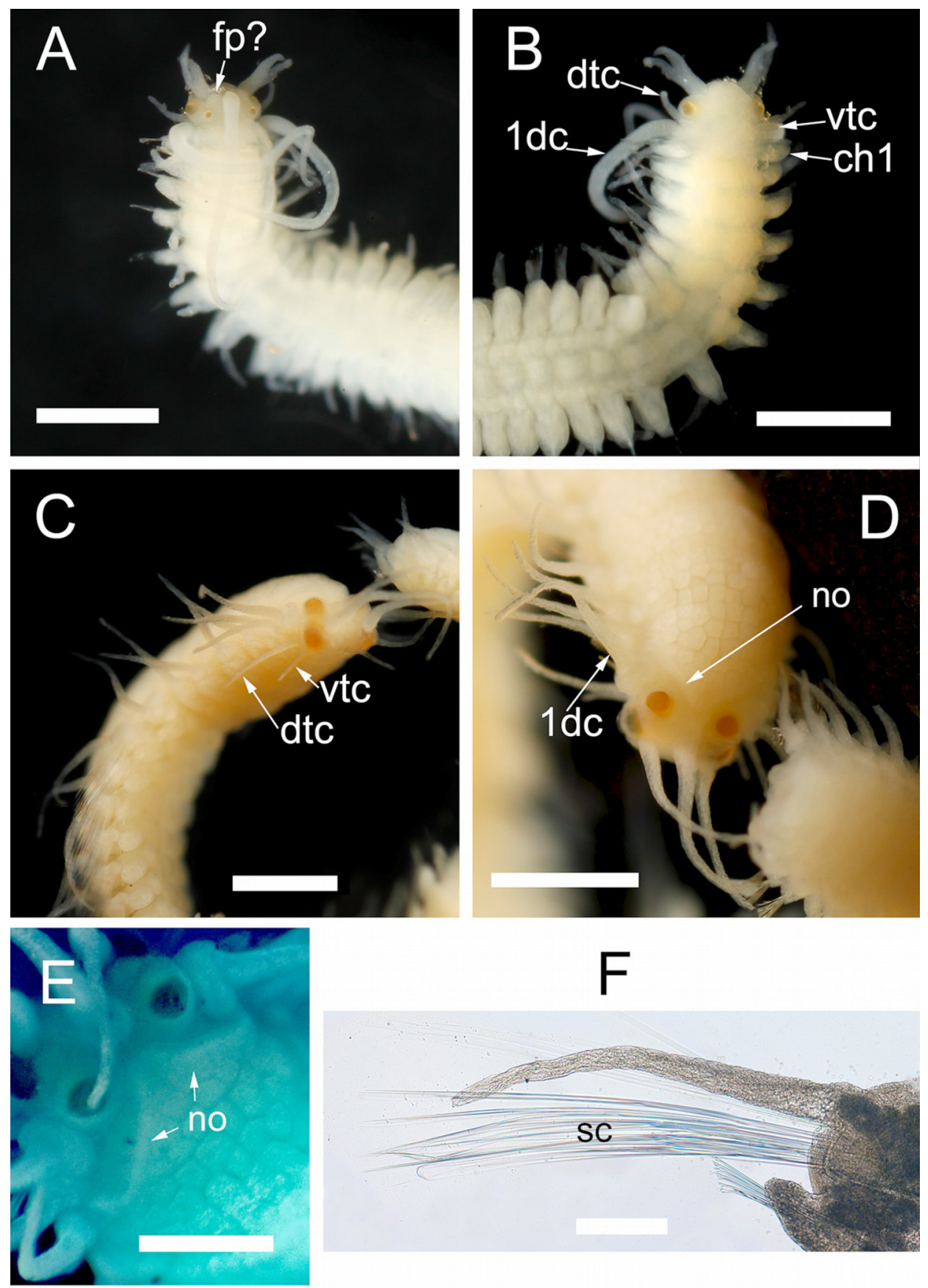

264 Figure 7. Proceraea exoryxae sp. nov. morphology of epitokes. Anterior end of male stolon 265 [MNCN 16.01/17721]: (A) dorsal view; (B) ventral view. Anterior end of female stolon [MNCN 
266 16.01/17722]: (C) anteroventral view; (D) dorsal view; (E) detail of prostomium showing the 267 nuchal organs (stained with methyl blue). (F) Mid-body parapodia of female stolon showing the 268 swimming chaetae [MNCN 16.01/17722]. Abbreviations as follows: dtc = dorsal tentacular cirri, $269 \mathrm{vtc}=$ ventral tentacular cirri, $1 \mathrm{dc}=$ first dorsal cirri, $\operatorname{ch} 1=$ chaetiger $1, \mathrm{fr}=$ frontal process, no $=$ 270 nuchal organs, $\mathrm{sc}=$ swimming chaetae. Scale bars $\mathrm{A}-\mathrm{D}=0.5 \mathrm{~mm}, \mathrm{E}, \mathrm{F}=100 \mu \mathrm{m}$.

271 Morphology of the epitokous female. Length $5 \mathrm{~mm}$ for $6+27+9$ chaetigers in region $\mathrm{a}, \mathrm{b}$ and $\mathrm{c}$ 272 (see Nygren 2004), incomplete; width in region a and c $0.6 \mathrm{~mm}$ excluding parapodial lobes, in 273 region b $1 \mathrm{~mm}$ including parapodial lobes. Colour of living individuals unknown. Preserved 274 specimen yellowish, with body filled by eggs (Fig. 7D); colour markings absent. Prostomium 275 rounded rectangular, wider than long, anterior margin straight. Four eyes with lenses, situated 276 ventro-lateral and dorsal on prostomium, ventro-lateral pair larger (Fig. 7C, D). Palps absent. 277 Nuchal organs reaching beginning of chaetiger 1 (Fig. 7D, E). Median antenna inserted medially 278 on prostomium, reaching c. chaetiger 5; lateral antennae inserted on anterior margin, about two 279 third in length of median antenna. Tentacular cirri 2 pairs (Fig. 7C), dorsal tentacular cirri, as long 280 as prostomial width, ventral tentacular cirri about $1 / 2$ as long as dorsal pair. First dorsal cirri (Fig. 7D), equal in length to lateral antennae. Achaetous knobs absent. Cirri in region a reciprocally equal, slightly shorter than first dorsal cirri, equal in length to body width excluding parapodial lobes, cirri in region b reciprocally equal, slightly longer than cirri in region a, cirri in region c reciprocally equal, slightly shorter than cirri in region a. Ceratophores on median and lateral antennae, cirrophores present on all dorsal cirri, but tentacular cirri without cirrophores. Antennae, tentacular cirri, and dorsal cirri cylindrical. Parapodia in region a uniramous, neuropodial lobes rounded, parapodia in region $b$ with additional notopodial lobes. Single neuropodial acicula in all chaetigers; $2-3$ anterodorsal and 6-7 posteroventral notopodial aciculae in region $b$. Neuropodial fascicle with 7-8 compound chaetae and a single bayonet chaeta of the same types described for the atokous form. Notopodial chaetal fascicle with 20-25 long and thin

291 swimming chaetae (Fig. 7F).

\section{DISCUSSION}


294 The combination of morphological features in Proceraea exoryxae sp. nov.makes it difficult to 295 place it in any specific genus within the Autolytinae. The thick type of bayonet chaeta, distally 296 denticulated, and the presence of cirrophores only on anterior-most cirri indicate, however, that 297 the new species is a member of the tribe Procerini. Accordingly, these morphological characters 298 are not found in either of the two other main groups (Autolytini and Epigamia).

299 We place the new species in the genus Proceraea even though simple chaetae (apart from 300 bayonet chaetae) are not found in any described member. We base our decision on the fact that 301 the trepan teeth in P. exoryxae sp. nov. are arranged in more than one ring, which is only found in 302 Proceraea among Procerini. The observation of the trepan rings is clear under SEM, despite part 303 of the dissected pharynx being still covered by tissue. The presence of simple chaetae in a restricted number of anterior chaetigers is a feature shared only with some members of Procerastea and Imajimaea among the Autolytinae, which differ in having trepans with a single ring, instead of separate rings as in $P$. exoryxae sp. nov. Moreover, simple chaetae in P. exoryxae sp. nov. differ from those in these two genera in that there seems to be two types. The first one (Fig. 4B 1-3) has a peculiar morphology with an enlarged, hooked tip surrounded by a distal half crown of small denticles. In the second type, the hooked tip progressively reduces its length (e.g. Fig. 4, 5-6) to finally acquire a shape almost non-distinguishable from the blades of compound chaetae (Fig. 4, 9). Only the first type of chaeta is present in the first chaetigers, and its number is progressively reduced to disappear around chaetiger 9-10. Conversely the second type progressively increased in number to be finally replaced by compound chaetae around chaetiger 10. At this level, it is almost impossible to distinguish between a simple chaeta and a compound one that has lost the blade. However, in mid-body and posterior segments, the presence of compound chaetae without blades is extremely rare. This, together with the fact that there is an antero-posterior gradation in tip length in the second type of simple chaetae supports they actually are simple chaetae instead of compound ones without blade.

Further, all members of Procerastea have thick, distally dilated, bayonet chaetae and have dorsal cirri only on the first chaetiger, while P. exoryxae sp. nov. has thick bayonet chaetae not distally dilated and dorsal cirri on all segments. Imajimaea, on the other hand, shares the presence of dorsal cirri on all its segments, except for I. draculai that lacks dorsal cirri on chaetigers 2-5. However, all species of Imajimaea have thin, subdistally denticulated, bayonet chaetae, and not thick bayonet chaetae, distally denticulated as in P. exoryxae sp. nov. 
327 region a, two pairs of tentacular cirri, and no achaetous knobs is found in Virchowia clavata

328 Langerhans, 1879, V. pectinans (Hartmann-Schröder, 1983), Autolytus emertoni Verrill, 1881, 329 Procerastea halleziana Malaquin, 1893, P. nematodes Langerhans, 1884, and Proceraea picta 330 Ehlers, 1864 (Nygren 2004). The information on the stolons of V. clavata, Procerastea spp. and 331 P. picta is based on the literature only, but even in the species where the stolons are thoroughly 332 described and illustrated, the achaetous knobs are not detailed. All other species assigned to 333 Proceraea for which stolons are known, i.e. P. cornuta (Agassiz, 1862), P. fasciata Bosc, 1802, 334 P. hanssoni Nygren, 2004, P. nigropunctata Nygren \& Gidholm, 2001, P. okadai (Imajima, 1966), 335 and $P$. prismatica (O.F. Müller, 1776), are equipped with achaetous knobs ventral to the first 336 dorsal cirri. It is important to note that molecular phylogenetic studies have found the genus 337 Proceraea to be paraphyletic without the inclusion of e.g. Virchowia, and Procerastea (e.g., 338 Nygren et al. 2010). Proceraea picta and close relatives are found as a sister group to a clade 339 where the Proceraea having stolons with achaetous knobs constitute the first subclade, and 340 Virchowia, Procerastea and other genera, whose known stolons lack achaetous knobs, constitute 341 the second subclade. This indicates that having stolons with achaetous knobs is the derived state, 342 while the lack of achetous knobs is plesiomorphic. A revision of Proceraea is clearly needed, but 343 beyond the scope of this paper. Until then, we consider a generic assignment to Proceraea for this 344 new species to be the best option.

\section{Autolytinid symbionts}

346 Despite the hundreds of symbiotic polychaete species known, including $>80$ species considered 347 parasitic, parasitism is relatively rare in this taxon when compared to other lifestyles (Martin \& 348 Britayev 1998; Britayev \& Lyskin 2002; Britayev et al. 2014). Most recorded symbiotic 349 associations between polychaetes and invertebrates involve sponge, cnidarian, mollusc, or 350 echinoderm hosts, but a few mention ascidians. Some previous reports of polychaetes living 351 among ascidians came from dredged or scraped-quadrat samples, which are usually inadequate to 352 determine symbiont-host associations because they result in specimen mixtures, while soft353 bodied animals, like tunicates or annelids, are often greatly damaged. In this context, the term 354 "associated with" most often refers to spatially co-occurring specimens. Nonetheless, high 355 densities of polychaetes, including syllids, are known to occur among the fauna associated with 356 particular benthic tunicates (e.g., Allen 1915; Fielding et al. 1994; Cerdá \& Castilla 2001; Fiore 357 \& Jutte 2010; Sepúlveda et al. 2015). Polychaetes were dominant on intertidal (but not subtidal) 
358 beds of Pyura stolonifera (Heller 1878), the second most abundant group in beds of the 359 congeneric P. praeputialis (Heller 1878) (Fielding et al. 1994; Cerdá \& Castilla 2001), and 360 constituted $28 \%$ of the fauna associated with didemnid ascidians (Fiore \& Jutte 2010). These 361 reports, however, largely refer to animals living in the sediments accumulated in the crevices 362 among ascidian aggregates and, thus, there is no reason to suspect true symbiotic interactions. 363 Similarly, intraspecific variation in growth form of Pyura chilensis Molina, 1782 has been 364 documented in response to the presence of chaetopterid polychaete tubes in the assemblage 365 (Sepúlveda et al. 2015), but this was interpreted as a density-dependent phenomenon not related 366 to symbiosis.

367 Other studies have documented serendipitous observations obtained while searching for 368 other ascidian associates. For example, in his monograph on ascidian-associated copepods, Illg 369 (1958) reported unidentified polychaetes from the atria and branchial sacs of dredged ascidians. 370 Similarly, Monniot (1990) reported ten unidentified Syllidae from the branchial sac of 371 Microcosmus anchylodeirus Traustedt, 1883. In summary, information on the nature of 372 polychaete-ascidian relationships remains very scarce. Most reports of polychaetes (and syllids in 373 particular) do not refer to individuals "living in association with" tunicates (which would imply 374 some degree of specialization and thus suggest any type of symbiotic interaction). In fact, there is 375 only one previous report specifically referring to a symbiosis, in which another autolytine, 376 Myrianida pinnigera, was found living in association with Ascidiella aspersa and Phallusia 377 mammilata (Table 1). Two decades later, Spooner et al. (1957) stated that this species feeds on 378 the body fluids of these and other ascidians from the British southern coast. While intriguing, this 379 interaction has never been quantitatively evaluated and the evidence for this specialized trophic 380 mode is still unclear. But if so, P. exoryxae sp. nov. is the second known polychaete, and the 381 second autolytine too, living in symbiosis with ascidians.

382 Table 1. List of known autolytinid syllids reported as symbionts. Cn: Cnidarians; Tu: tunicates.

\begin{tabular}{|c|c|c|c|}
\hline SYMBIONT & & HOST & REFERENCES \\
\hline \multirow[t]{2}{*}{ Proceraea $\mathrm{sp}}$. & $\mathrm{Cn}$ & $\begin{array}{l}\text { Abietinaria turgida (Clarke } \\
\text { 1877) }\end{array}$ & $\begin{array}{l}\text { (Britayev \& San Martín } \\
\text { 2001) }\end{array}$ \\
\hline & $\mathrm{Cn}$ & $\begin{array}{l}\text { Orthopyxis integra (Macgillivray } \\
\text { 1842) }\end{array}$ & $\begin{array}{l}\text { T.A. Britayev, personal } \\
\text { communication }\end{array}$ \\
\hline $\begin{array}{l}\text { Imajimaea draculai (San Martín } \\
\text { \& López 2002) }\end{array}$ & $\mathrm{Cn}$ & $\begin{array}{l}\text { Funiculina quadrangularis } \\
\text { (Pallas 1766) }\end{array}$ & (Nygren \& Pleijel 2010) \\
\hline \multirow[t]{2}{*}{$\begin{array}{l}\text { Myrianida piningera (Montagu } \\
\text { 1808) }\end{array}$} & $\mathrm{Tu}$ & $\begin{array}{l}\text { Phallusia mammillata (Cuvier } \\
\text { 1815) }\end{array}$ & $\begin{array}{l}\text { (Okada 1935; Spooner et } \\
\text { al. 1957) }\end{array}$ \\
\hline & $\mathrm{Tu}$ & $\begin{array}{l}\text { Ascidiella aspersa (O. F. Müller } \\
\text { 1776) }\end{array}$ & $\begin{array}{l}\text { (Okada 1935; Spooner et } \\
\text { al. 1957) }\end{array}$ \\
\hline
\end{tabular}




\begin{tabular}{|c|c|c|c|}
\hline Procerastea cornuta Agassiz, & $\mathrm{Cn}$ & Unidentified hydroid & (Pettibone 1963) \\
\hline \multirow{5}{*}{$\begin{array}{l}\text { Procerastea halleziana } \\
\text { Malaquin, } 1893\end{array}$} & $\mathrm{Cn}$ & Unidentified Coral & (Gardiner 1976) \\
\hline & $\mathrm{Cn}$ & Ectopleura crocea (Agassiz & (Genzano \& San Martín \\
\hline & & 1862) & 2002) \\
\hline & $\mathrm{Cn}$ & Coryne eximia Allman, 1859 & $\begin{array}{l}\text { (Allen 1915; Allen 1923; } \\
\text { Alós 1989; Spooner et al. } \\
\text { 1957) }\end{array}$ \\
\hline & $\mathrm{Cn}$ & $\begin{array}{l}\text { Tubularia indivisa Linnaeus, } \\
1758\end{array}$ & $\begin{array}{l}\text { (Caullery 1925; Spooner et } \\
\text { al. 1957) }\end{array}$ \\
\hline Proceraea penetrans (Wright \& & $\mathrm{Cn}$ & Stylaster californicus (Verrill & (Wright \& Woodwick \\
\hline $\begin{array}{l}\text { Proceraea madeirensis Nygren, } \\
2004\end{array}$ & $\mathrm{Cn}$ & $\begin{array}{l}\text { Eudendrium carneum Clarke, } \\
1882\end{array}$ & $\begin{array}{l}\text { E. Cruz-Rivera, personal } \\
\text { observations }\end{array}$ \\
\hline $\begin{array}{l}\text { Pachyprocerastea hydrozoicola } \\
\text { (Hartmann-Schröder 1992) }\end{array}$ & $\mathrm{Cn}$ & Pseudosolanderia sp. & (Hartmann-Schröder 1992) \\
\hline Procerastea parasimpliseta & $\mathrm{Cn}$ & Pseudosolanderia sp. & (Hartmann-Schröder 1992) \\
\hline Hartmann-Schröder, 1992 & & & \\
\hline
\end{tabular}

In addition to these two species of tunicate associates, eight more autolytines have been previously reported as living in symbiosis with other invertebrates, all them cnidarians (Table 1). Most of them are considered parasites, although only some are sufficiently studied to be clearly defined as such (Martin \& Britayev 1998). Among the best documented, Proceraea penetrans (Wright \& Woodwick, 1977) induces galls on its hydrocoral hosts, while Proceraea sp. modifies the theca of polyps in its hydroid hosts in order to live inside, probably feeding on the polyps themselves ( Britayev et al. 1998; Britayev \& San Martín 2001).

\section{Proceraea exoryxae sp. nov. as a miner}

The association of $P$. exoryxae sp. nov. with $P$. nigra appears to be extremely rare, as there was only one infested host among all those we examined. The presence of a polychaete inside the tunic of P. nigra has not been reported in previous studies at the same and other reefs (Kim et al. 2016). As mentioned above, parasitism is an atypical phenomenon among polychaetes, but also parasitic species are, with a few exceptions, extremely rare. In fact, many symbiotic polychaetes are only known from a single specimen (or very few) found only once (Martin \& Britayev, 1998). The reasons for this rarity are often unknown. We may speculate that the lack of dedicated studies may be the actual reason in many cases, although that seems unlikely for P. exoryxae sp. nov., which was discovered during multi-year monitoring of the associated fauna of the host ascidian (Kim et al. 2016). We could also hypothesize that the parasite is a recent introduction from an 
401 unknown origin, but this also seems unlikely because the host is a Red Sea endemic ascidian 402 (Vandepas et al. 2015) and specialist parasites would be expected to occur in areas where hosts 403 have the longest evolutionary history. More reasonably, either the polychaete occurs only 404 infrequently and is thus difficult to find, or its peculiar and hidden habitat may have caused it to 405 be overlooked in previous studies. We can also not discard the possibility that the parasitic mode 406 of life may be just a phase in the life cycle of the worm, possibly connected to reproduction, as 407 inferred from the presence of epitokous forms among atokes. This would add a temporal 408 component to the presence of $P$. exoryxae sp. nov. inside $P$. nigra, that would increase the 409 difficulty in finding it.

410 Despite (and, maybe, due to) its rarity, Proceraea exoryxae sp. nov. is the first polychaete 411 formally defined as miner and, certainly, the first of Autolytinae. We use the term mining as it is 412 often used to describe insects that tunnel through the tissues of their plant hosts (Connor \& 413 Taverner 1997; Sinclair \& Hughes 2010; Mejaes et al. 2015), but also marine isopods tunnelling 414 seagrass leaves (Brearley \& Walker 1995). This is also the mechanism we suggest for the 415 formation of the galleries in the P. nigra tunic where $P$. exoryxae sp. nov. was found. The rarity 416 of the polychaete precluded a thorough assessment of the host-symbiont interaction although, as 417 in the case of $M$. pinnigera, the new species possibly feeds on the tissues of the host ascidian. 418 Nonetheless, it represents the first clear example of mechanical damage by a polychaete on an 419 ascidian, and as such, we classify the interaction as a parasitic symbiosis (Castro 2015). The 420 defensive characteristics attributed to the P. nigra tunic, which include the accumulation of 421 vanadium and sulfuric acid, and their derived metabolites (Stoecker 1980; Hirose et al. 2001; 422 Pisut \& Pawlik 2002; Odate \& Pawlik 2007), did not prevent infestation by P. exoryxae sp. nov., 423 while they have been suggested to prevent infestation by the bivalve Musculus subpictus 424 (Cantraine 1835) in an population introduced in Panama (Cañete \& Rocha 2013). Because both 425 the host and polychaete symbiont were likely at their native habitat, and because symbionts are often unaffected by host defensive metabolites, the new partnership here reported may imply a noticeable degree of specialisation. The presence of epitokous forms certainly confirms that at 428 least the first phases of the reproductive cycle of the species (i.e. stolon formation) occurred inside the galleries, which may be considered as an additional evidence of specialization. 430 However, whether $P$. exoryxae sp. nov. is an exclusive parasite of $P$. nigra or infests other 431 ascidians awaits further studies.

432 Although rare for polychaetes, many invertebrates are known to live in symbiotic 433 associations with ascidians, including amphipods, shrimps, copepods, pinnotherid crabs, 
434 nemerteans and cnidarians (e.g., Illg 1958; Stock 1967; Boxshall 2005; Lambert 2005; Monniot 435 1990; Thiel 2000; Baeza \& Díaz-Valdés 2011; White 2011; Kim et al. 2016). Most of these 436 animals live in the branchial sac of the host and are often considered commensals, with the 437 exception of some copepod taxa, which are largely classified as ectoparasites on this respiratory 438 organ (Illg 1958; Stock 1967; Boxshall 2005; Kim et al. 2016). In contrast, but perhaps not 439 surprisingly, few animals have evolved to inhabit the ascidian tunic, which is often structurally 440 tough, and may contain spicules, inorganic acids, concentrated vanadium, and a variety of 441 defensive secondary chemicals (Stoecker 1980; Pisut \& Pawlik 2002; Joullié et al. 2003; Odate \& 442 Pawlik 2007; Koplovitz et al. 2009). Some mytilid mussels in the genera Mytilimeria and 443 Musculus (=Modiolarca) are symbiotic bivalves that live completely embedded in the tunic of 444 their ascidian host (Say 1822; White 1949; Lambert 2005; Morton \& Dinesen 2011; Cañete \& 445 Rocha 2013). Similarly, two species of amphipods in the genus Polycheria live by filter feeding 446 from individual shallow pockets they excavate on the tunic of their host ascidians (Skogsberg \& 447 Vansell 1928; McClintock et al. 2009). Recently, the parasitic copepod Janstockia phallusiella 448 Boxshall and Marchenkov, 2005 has been reported as living attached to the atrial wall of P. nigra 449 (Kim et al. 2016). None of these animals, however, produce a network of tunnels similar to that 450 observed in the specimen of $P$. nigra infested by $P$. exoryxae sp. nov.

451 Among polychaetes several species are known to inhabit excavated galleries. Probably the 452 best known are polydorid spionids, which include numerous species from different genera that 453 burrow into calcareous substrates, including algae, crustacean carapaces, and mollusc shells. 454 Some of them are simple borers, but others are well known commensals and parasites, sometimes 455 being even considered as pests when they infest species of commercial interest (Martin \& 456 Britayev 1998). Although less diverse, similar habits are also present among cirratulids and 457 sabellids, the latter being also able to infest fresh water invertebrates (Martin \& Britayev 1998). 458 Polychaetes are also known to excavate galleries in seagrasses (Guidetti 2000; Gambi et al. 459 2003), cnidarians (Martin et al. 2002; Cairns 2006; Cairns \& Bayer 2008; Cairns 2009; Cairns 460 2011; Cairns 2012; Mueller et al. 2013; Britayev et al. 2014; Molodtsova et al. 2016) and sponges 461 (see Lattig \& Martin 2011 and references herein). Seagrass associated polychaetes are mainly 462 detritivores that bore into the dead sheath tissues (Gambi et al. 2003), but their galleries are also 463 present in living meristems and leaves that have been reported as "mined" tissues (Guidetti 464 2000). Cnidarian associates (e.g. polynoids, eunicids, syllids) may inhabit depressions in the host 465 skeleton that are usually covered by overgrowing host tissues and/or skeleton to form tunnels or 466 galleries, presumably as a reaction to the symbionts' presence (Britayev et al. 2014). A particular 
467 case is that of Haplosyllis anthogorgicola Utinomi, 1956, which excavates a network of galleries

468 inside the soft tissues of its host gorgonian. Host tissue overgrowths are limited to small tube-like 469 protuberances at the gallery exits, from where the worms supposedly feed by stealing food from 470 the nearby host polyps (Martin et al. 2002). Polychaete sponge borers are mainly syllids (e.g. 471 Haplosyllis, Haplosyllides), which may either inhabit the aquiferous channels of the sponge or 472 excavate their own galleries inside the host tissues (Martin \& Britayev 1998; Martin et al. 2009; 473 Lattig \& Martin 2011).

474 When observing the tunic of the Red Sea specimen of P. nigra we did not detected traces of 475 external overgrowths associated to the gallery openings and, when dissecting the excavated galleries, we did not find any induced malformations or defined cavities (like cysts, galls or blisters). Conversely, there was a thin, translucent layer covering the galleries. Likely, this was an inner lining secreted by the worms to cover the tunnel walls, possibly made in a similar fashion as the hyaline tubes that some autolytines build to remain attached to their host cnidarians (Molodtsova et al. 2016). At present, the mechanics of excavating tunnels by P. exoryxae sp. nov. are unknown, but the typical syllid feeding structures (i.e., trepan, evaginable pharynx and sucking proventricle) seem to be a perfect combination enabling P. exoryxae sp. nov. for this particular task.

In addition to possible affectations to host fitness, the parasitic mode of life attributed to $P$. exoryxae sp. nov. may also be relevant for coastal management. Being native from the Red Sea, P. nigra has been introduced worldwide in tropical and sub-tropical ecosystems (Shenkar 2012; Vandepas et al. 2015) where, as many other tunicates (Zhan et al. 2015), it has the potential of becoming invasive. Accordingly, three interesting questions remain open for further studies: 1) whether the parasitic $P$. exoryxae sp. nov. may be (or has already been) introduced together with the ascidian, 2) whether it may contribute to control the spreading of P. nigra in non-native regions, and 3) whether it may switch its host to infest, and thus cause damage, to native ascidians in the regions were the Red Sea host/parasite partnership has been introduced. In combination with molecular tools to trace the origin of an introduced species, the existence of a specialized parasite known only from the native host population may also help assess whether the host species has been introduced directly from this native population or indirectly from an already introduced population (MacKenzie 1993, 2002; Catalano et al. 2014). Nevertheless, the actual relevance of the association may be obscured by its rarity and, thus, will certainly rely on a future confirmation of its actual prevalence, as well as on the assessment of spatial and temporal extension of the infestation. 
500

\section{Acknowledgments}

EC-R acknowledges the Department of Biological Sciences, University of the Virgin Islands for time release during the preparation of this article. Hussa Al Ajeer, Ali Fahmi, Maricel Flores-Díaz, and Tamer Hafez, helped with specimen collection and ascidian dissections. We thank the staff of the J. D. Gerhart Field Station for support during our fieldwork and Dr X. Turon from the CEAB-CSIC for his advice on tunicate associates. María García, from the SEM service at the CEAB-CSIC, kindly helped with the SEM observations. This paper is contribution \#175 from the Center for Marine and Environmental Sciences, University of the Virgin Islands (EC-R), and a contribution of DM to the research project MarSymBiomics and the Consolidated Research Group on Marine Benthic Ecology.

\section{References}

Agassiz A. 1862. On alternate generation of annelids and the embryology of Autolytus cornutus. Journal of the Boston Society for Natural History 7:384-409.

Aguado MT, San Martín G. 2009. Phylogeny of Syllidae (Polychaeta) based on morphological data. Zoologica Scripta 38:379-402 DOI 10.1111/j.1463-6409.2008.00380.x.

Aguirre L, San Martín G, Álvarez-Campos P. 2016. Autolytinae from Peru: description of Myrianida paredesi sp. nov. and new records of Myrianida pentadentata (Imajima, 1966), and Proceraea micropedata (Hartmann-Schröder, 1962). Journal of the Marine Biological Association of the United Kingdom 96:1633-1649 DOI 10.1017/S0025315415002015.

Allen EJ. 1915. Polychaeta of Plymouth and the South Devon coast, including a list of the Archiannelida. Journal of the Marine Biological Association of the United Kingdom 10: 592-646 DOI 10.1017/S002531540000919X.

Allen EJ. 1923. Regeneration and reproduction of the syllid Procerastea. Philosophical Transactions of the Royal Society of London 211:131-177.

Allman GJ. 1859. V.--Notes on the Hydroid zoophytes. Annals and Magazine of Natural History 4:137-144. 
526

527

528

529

530

531

532

533

534

535

536

537

538

539

540

541

542

543

544

545

546

547

548

549

550

551

552

553

554

555

556

557

558

Alós C. 1989. Adiciones a la fauna de Anélidos Poliquetos de la península Ibérica: familia Syllidae. Cahiers de Biologie Marine 30:329-337.

Álvarez-Campos P, San Martín G, Piotrowiski C. 2014. A new species of Myrianida Milne Edwards, 1845 (Autolytinae: Syllidae: Annelida), from Luzón, Philippine Islands. Special Publication of the California Academy of Sciences, The Coral Triangle - The Hearst Biodiversity Expedition to the Philippines, 2011, 145-154.

Baeza JA, and Díaz-Valdés M. 2011. The symbiotic shrimp Ascidonia flavomaculata lives solitarily in the tunicate Ascidia mentula: implications for its mating system. Invertebrate Biology 130:351-361 DOI 10.1111/j.1744-7410.2011.00244.x.

Bosc LAC. 1802. Histoire naturelles des vers, contenant leur description et leur moeurs avec figures dessinees d'apres nature. Paris: Deterville Libraire.

Boxshall G. 2005. A synthetic summary of the biology of parasitic copepods in a marine environment. Marine parasitology. Wallingford: CABI Publishing, 123-138.

Boxshall GA, Marchenkov A. 2005. A new genus of notodelphyid copepod (Crustacea, Copepoda, Cyclopoida) from a compound ascidian host collected in the Suez Canal. Zoosystema 27:483-497.

Brearley A, Walker D. 1995. Isopod miners in the leaves of two Western Australian Posidonia species. Aquatic Botany 52:163-181 DOI 10.1016/0304-3770(95)00493-9.

Britayev TA, Gil J, Altuna A, Calvo M, Martin D. 2014. New symbiotic associations involving polynoids (Polychaeta, Polynoidae) from Atlantic waters, with redescriptions of Parahololepidella greeffi (Augener, 1918) and Gorgoniapolynoe caeciliae (Fauvel, 1913). Memoirs of Museum Victoria 71:27-43.

Britayev TA, Lyskin SA. 2002. Feeding of the symbiotic polychaete Gastrolepidia clavigera (Polynoidae) and its interactions with its hosts. Doklady Biological Sciences 385:352-356 DOI: 10.1023/A:1019964918471.

Britayev TA, San Martín G. 2001. Description and life-history traits of a new species of Proceraea with larvae infecting Abietinaria turgida (Polychaeta, Syllidae and Hydrozoa, Sertulariidae). Ophelia 54:105-113 DOI 10.1080/00785236.2001.10409458.

Britayev TA, San Martín G, Sheiko O. 1998. Symbiotic Polychaetes Proceraea sp. (Polychaeta, Syllidae) and modification of hydrothecae in hydroid Abietinaria turgida (Hydrozoa, Sertullariidae). Zoologicheskii Zhurnal 77:527-532.

Cairns SD. 2006. Studies on western Atlantic Octocorallia (Coelenterata: Anthozoa). Part 6: The genera Primnoella Gray, 1858; Thouarella Gray, 1870; Dasystenella Versluys, 1906. 

324X(2006)119[161:SOWAOC]2.0.CO;2.

561 Cairns SD. 2009. Review of Octocorallia (Cnidaria: Anthozoa) from Hawaii and adjacent seamounts. Part 2: Genera Paracalyptrophora Kinoshita, 1908; Candidella Bayer, 1954; and Calyptrophora Gray, 1866. Pacific Science 63:413-448 DOI 10.2984/049.063.0309.

Cairns SD. 2011. A revision of the Primnoidae (Octocorallia: Acyonacea) from the Aleutian Islands and Bering Sea. Smithsonian Contributions to Zoology 634:1-55.

Cairns SD. 2012. New Zealand Primnoidae (Anthozoa: Alcyonacea)-Part 1: Genera Narella, Narelloides, Metanarella, Calyptrophora, and Helicoprimnoa. NIWA Biodiversity Memoirs 126:1-72.

Cairns SD, Bayer FM. 2008. A Review of the Octocorallia (Cnidaria: Anthozoa) from Hawaii and Adjacent Seamounts: The Genus Narella Gray, 1870. Pacific Science 62:83-115 DOI 10.2984/1534-6188(2008)62[83:AROTOC]2.0.CO;2.

Cañete JI, Rocha RM. 2013. Modiolarca lateralis (Pteryomorphia: Mytilidae): bivalve associated to six species of ascidians from Bocas del Toro, Panama. Latin American Journal of Aquatic Research 41:1030-1035. DOI 103856/vol41-issue5-fulltext-25

Cantraine F. 1835. Diagnoses ou descriptions succinctes de quelques espèces nouvelles de mollusques, qui feront partie de l'ouvrage Malacologie mediterranéenne et littorale, et comparaisons des coquilles qu'on trouve dans les collines subapennines avec celles qui vivnet encore dans nos mers. Bulletin de l'Académie Royale des Sciences et Belles-lettres de Bruxelles 2:380-411.

Castro P. 2015. Symbiotic Brachyura. In: Castro P, Davie P, Guinot D, Schram FR, and von Vaupel Klein JC, eds. Treatise on Zoology-Anatomy, Taxonomy, Biology The Crustacea, Volume 9 Part C (2 vols). Leiden: Brill, 543-581.

Catalano SR, Whittington ID, Donnellan SC, Gillanders BM. 2014. Parasites as biological tags to assess host population structure: guidelines, recent genetic advances and comments on a holistic approach. International Journal for Parasitology: Parasites and Wildlife 3: 220-226 DOI 10.1016/j.ijppaw.2013.11.001.

Caullery M. 1925. Schizogenese et schizogamie de Procerastea halleziana Malaquin. Parasitism de ce Syllidien sur les Tubulaires. Bulletin de la Société Zoologique de France 50:204-208.

Cerdá M, Castilla JC. 2001. Diversidad y biomasa de macro-invertebrados en matrices intermareales del tunicado Pyura praeputialis (Heller, 1878) en la Bahía de Antofagasta, 
Chile. Revista Chilena de Historia Natural 74:841-853. DOI 10.4067/S0716078X2001000400011.

594 Çinar ME. 2015. A new species of Myrianida (Polychaeta: Syllidae: Autolytinae) from Rhodes Kingdom 95:1101-1104. doi:10.1017/S0025315415000107.

Çinar ME, Gambi MC. 2005. Cognetti's syllid collection (Polychaeta: Syllidae) deposited at the Museum of the Stazione Zoologica “Anton Dohrn” (Naples, Italy), with descriptions of two new species of Autolytus. Journal of Natural History 39:725-762 DOI $10.1080 / 00222930400001327$

Clarke SF. 1877. Report on the hydroids collected on the coast of Alaska and the Aleutian Islands by W.H. Dall, U.S. Coast Survey, and party, from 1871 to 1874 inclusive. Proceedings of the Academy of Natural Sciences of Philadelphia 1876:209-238, plates 207216.

Clarke SF. 1882. New and Interesting Hydroids from the Chesapeake Bay. Memoirs of the Boston Society of Natural History 3:135142.

Connor EF, Taverner MP. 1997. The evolution and adaptive significance of the leaf-mining habit. Oikos 79 :6-25 DOI 10.2307/3546085.

Cuvier G. 1815. Mémoire sur les Ascidies et sur leur anatomie. Annales du Muséum d'Histoire Naturelle de Paris 2:10-39.

Dietrich A, Hager T, Bönsch R, Winkelmann C, Schmidt A, Nygren A. 2015. A new species of Myrianida (Autolytinae, Syllidae, Annelida) from the North Sea, with short notes on the distribution and habitat of Northeast Atlantic autolytines. Marine Biology Research 11:804813. DOI 10.1080/17451000.2015.1016971

Fauchald K, Jumars PA. 1979. The diet of worms: A study of polychaete feeding guilds. Oceanography and Marine Biology: An Annual Review 17:193-284.

Fielding P, Weerts K, Forbes A. 1994. Macroinvertebrate communities associated with intertidal and subtidal beds of Pyura stolonifera (Heller)(Tunicata: Ascidiacea) on the Natal coast. South African Journal of Zoology 29:46-53 DOI 10.1080/02541858.1994.11448326.

Fiore CL, Jutte PC. 2010. Characterization of macrofaunal assemblages associated with sponges and tunicates collected off the southeastern United States. Invertebrate Biology 129:105-120. DOI 10.1111/j.1744-7410.2010.00184.x

Fischer A, Mewes K, Franke HD. 1992. Stolonization and mating behavior of Autolytus prolifer (Polychaeta). Göttingen, Box 2351, D-37013: Institute of the Scientific Film. 
625

626

627

628

629

630

631

632

633

634

635

636

637

638

639

640

641

642

643

644

645

646

647

648

649

650

651

652

653

654

655

656

657

Franke HD. 1999. Reproduction of the Syllidae (Annelida: Polychaeta). Hydrobiologia 402:39-55 DOI 10.1023/A:1003732307286.

Gambi MC, van Tussenbroek BI, Brearley A. 2003. Mesofaunal borers in seagrasses: worldwide occurrence and a new record of boring polychaetes in the Mexican Caribbean. Aquatic Botany 76:65-77 DOI 10.1016/s0304-3770(03)00031-7.

Gardiner SL. 1976. Errant Polychaete Annelids from North Carolina. Journal of the Elisha Mitchell Scientific Society 91:77-220.

Genzano GN, San Martín G. 2002. Association between the polychaete Procerastea halleziana (Polychaeta: Syllidae: Autolytinae) and the hydroid Tubularia crocea (Cnidaria: Hydrozoa) from the Mar del Plata intertidal zone, Argentina. Cahiers de Biologie Marine 43:165-170.

Gidholm L. 1967. A revision of Autolytinae (Syllidae, Polychaeta) with special reference to Scandinavian species, and with notes on external and internal morphology, reproduction and ecology. Arkiv för Zoologi 19:157-213.

Guidetti P. 2000. Invertebrate borers in the Mediterranean seagrass Posidonia oceanica: biological impact and ecological implications. Journal of the Marine Biological Association of the United Kingdom 80:725-730.

Hamond R. 1969. On the preferred foods of some autolytoids (Polychaeta, Syllidae). Cahiers de Biologie Marine 10:439-445.

Hartmann-Schröder G. 1992. Drei neue Polychaeten-arten der familien Polynoidae und Syllidae von Neu-Kaledonien, assoziiert mit einer verkalten Hydrozoe. Helgoländer Meeresuntersuchungen 46:93-101 DOI 10.1007/BF02366214.

Heller C. 1878. Beitrage zur nähern Kenntniss der Tunicaten. Sitzungsberichte der Akademie der Wissenschaften in Wien 77:83-109.

Hirose E, Yamashiro H, Mori Y. 2001. Properties of tunic acid in the ascidian Phallusia nigra (Ascidiidae, Phlebobranchia) Zoological Science 18:309-314 DOI 10.2108/zsj.18.309.

Illg PL. 1958. North American copepods of the family Notodelphyidae. Proceedings of the United States National Museum 107:463-659 DOI 10.5479/si.00963801.108-3390.463.

Joullié MM, Leonard MS, Portonovo P, Liang B, Ding X, La Clair JJ. 2003. Chemical defense in ascidians of the Didemnidae family. Bioconjugate Chemistry 14:30-37 DOI $10.1021 / \mathrm{bc} 025576 \mathrm{n}$.

Kim I-H, Cruz-Rivera E, Sherif M-E-D, El-Sahhar S. 2016. Cyclopoid copepods (Ascidicolidae, Notodelphyidae) associated with Phallusia nigra Savigny, 1816 (Ascidiacea) 
658

659

660

661

662

663

664

665

666

667

668

669

670

671

672

673

674

675

676

677

678

679

680

681

682

683

684

685

686

687

688

in the Red Sea: a new ascidicolid and first descriptions of the males from two notodelphyids. Journal of Crustacean Biology 36:553-566 DOI 10.1163/1937240X-00002439.

Koplovitz G, McClintock JB, Amsler CD, and Baker BJ. 2009. Palatability and chemical anti-predatory defenses in common ascidians from the Antarctic Peninsula. Aquatic Biology 7:81-92 DOI 10.3354/ab00188.

Lambert G. 2005. Ecology and natural history of the protochordates. Canadian Journal of Zoology 83:34-50 DOI 10.1139/z04-156.

Lattig P, Martin D. 2011. Sponge-associated Haplosyllis (Polychaeta: Syllidae: Syllinae) from the Caribbean Sea, with the description of four new species. Scientia Marina 75:733-758 DOI 10.3989/scimar.2011.75n4733.

Linnaeus C. 1758. Systema Naturae per Regna Tria Naturae, Secundum Classes, Ordines, Genera, Species, cum characteribus, differentiis, synonymis, locis. Tomus I. Editio Decima, Reformata. Stockholm: Laurentii Salvii.

Lucas Y, San Martín G, Sikorski A. 2010. A new genus and species of Syllidae (Annelida: Polychaeta) from off the coast of Norway with unusual morphological characters and an uncertain systematic position. Proceedings of the Biological Society of Washington 123:251257. DOI 10.2988/09-11.1.

Macgillivray J. 1842. L.-Catalogue of the Marine Zoophytes of the neighbourhood of Aberdeen. Annals and Magazine of Natural History 9:462-469 DOI 10.1080/03745484209445365.

MacKenzie, K. 1993. Parasites as biological indicators. Bulletin if the Scandinavian Society for Parasitology 3: 1-10.

MacKenzie, K. 2002. Parasites as biological tags in population studies of marine organisms: an update. Parasitology 124: 153-163 DOI 10.1017/S0031182002001518.

Malaquin A. 1893. Recherches sur les syllidiens: morphologie, anatomie, reproduction, développement. Mémoires de la Société des Sciences, de l'Agriculture et des Arts de Lille, 4e série 18:1-477.

Martin D, Aguado MT, Britayev TA. 2009. Review of the symbiotic genus Haplosyllides, with description of a new species. Zoological Science 26:646-655 DOI 10.2108/zsj.26.646.

Martin D, Britayev TA. 1998. Symbiotic polychaetes: Review of known species. Oceanography and Marine Biology: An Annual Review 36:217-340. 
689

690

691

692

693

694

695

696

697

698

699

700

701

702

703

704

705

706

707

708

709

710

711

712

713

714

715

716

717

718

719

720

Martin D, Britayev TA, San Martín G, Gil J. 2003. Inter-population variability and character description in the sponge associated Haplosyllis spongicola complex (Polychaeta: Syllidae). Hydrobiologia 496:145-162 DOI 10.1007/978-94-017-0655-1_14.

Martin D, Gil J, Abgarian C, Evans E, Turner EM, Jr., Nygren A. 2015. Proceraea janetae sp. nov. (Annelida, Syllidae, Autolytinae), a scleractinian coral feeder from Grand Cayman Island. Journal of the Marine Biological Association of the United Kingdom 95:703 - 712 DOI 10.1017/S0025315414001428.

Martin D, Núñez J, Riera R, Gil J. 2002. On the associations between Haplosyllis (Polychaeta, Syllidae) and gorgonians (Cnidaria, Octocorallaria), with a description of a new species. Biological Journal of the Linnean Society 77:455-477 DOI 10.1046/j.10958312.2002.00117.x.

McClintock JB, Amsler MO, Koplovitz G, Amsler CD, Baker BJ. 2009. Observations on an association between the dexaminid amphipod Polycheria antarctica F. Acanthopoda and its ascidian host Distaplia cylindrica. Journal of Crustacean Biology 29:605-608 DOI 10.1651/09-3146.1.

Mejaes BA, Poore AG, Thiel M. 2015. Crustaceans inhabiting domiciles excavated from macrophytes and stone. The Life Styles and Feeding Biology of the Crustacea 2:118-144.

Molina GI. 1782. Versuch einer Naturgeschichte von Chili.4. Viertes Buch. Würmer, Insekten, Amphibien, Fische, Vögel und vierfüssige Thiere von Chili. Leipzig: Friedrich Gotthold Jacobäer.

Molodtsova T, Britayev TA, Martin D. 2016. Chapter 25. Cnidarians and their polychate symbionts. In: Goffredo S, and Dubinsky Z, eds. The Cnidaria, past, present and future The world of Medusa and her sisters Switzerland: Springer International Publishing, 387-413 DOI 10.1007/978-3-319-31305-4_25.

Montagu G. 1808. II. Description of several Marine Animals found on the South Coast of Devonshire. Transactions of the Linnean Society of London 9:81-114 DOI 10.1111/j.10963642.1818.tb00327.x.

Morton B, Dinesen GE. 2011. The biology and functional morphology of Modiolarca subpicta (Bivalvia: Mytilidae: Musculinae), epizoically symbiotic with Ascidiella aspersa (Urochordata: Ascidiacea), from the Kattegat, northern Jutland, Denmark. Journal of the Marine Biological Association of the United Kingdom 91:1637-1649 DOI 10.1017/S0025315410001980. 
721 Mueller CE, Lundälv T, Middelburg JJ, van Oevelen D. 2013. The symbiosis between

722 Lophelia pertusa and Eunice norvegica stimulates coral calcification and worm assimilation.

$723 \quad P L O S O N E$ 8:e58660 DOI 10.1371/journal.pone.0058660.

724 Müller OF. 1776. Zoologicae Danicae Prodromus, seu Animalium Daniae et Norvegiae 725 indigenarum characteres, nomina et synonyma imprimis popularium. Havniae 726 [Copenhagen]: Hallageriis.

727 Nygren A. 2004. Revision of Autolytinae (Syllidae: Polychaeta). Zootaxa 680:1-314 DOI $728 \quad 10.11646 /$ zootaxa.680.1.1.

729 Nygren A, Pleijel F. 2007. A new species of Myrianida (Syllidae, Polychaeta) from Belize. 730 Zootaxa 1595:17-29 DOI 10.5281/zenodo.178674.

Nygren A, Pleijel F. 2010. Redescription of Imajimaea draculai - a rare syllid polychaete associated with the sea pen Funiculina quadrangularis. Journal of the Marine Biological Association of the United Kingdom 90:1441 -1448. DOI 10.1017/S0025315409991536

Nygren A, Sundberg P. 2003. Phylogeny and evolution of reproductive modes in Autolytinae (Syllidae, Annelida). Molecular Phylogenetics and Evolution 29:235-249 DOI 10.1016/S1055-7903(03)00095-2

Nygren A, Sundkvist T, Mikac B, Pleijel F. 2010. Two new and two poorly known autolytines (Polychaeta: Syllidae) from Madeira and the Mediterranean Sea. Zootaxa 2640:35-52 DOI 10.5281/zenodo.198574.

Odate S, Pawlik JR. 2007. The role of vanadium in the chemical defense of the solitary tunicate, Phallusia nigra. Journal of Chemical Ecology 33:643-654 DOI 10.1007/s10886007-9251-z.

Okada YK. 1928. Feeding organs and feeding habits of Autolytus edwardsi St. Joseph. Quarterly Journal of Microscopical Science, London 72:219-245.

Okada YK. 1935. Stolonization in Myrianida. Journal of the Marine Biological Association of the United Kingdom 20:93-98 DOI 10.1017/S0025315400010079.

Pallas PS. 1766. Miscellanea Zoologica. Quibus novae imprimis atque obscurae animalium species describuntur et observationibus iconibusque illustrantur: Hagae Comitum apud Petrum van Cleef.

Pettibone MH. 1963. Marine polychaete worms of the New England region. Part 1. Families Aphroditidae through Trochochaetidae. Bulletin of the United States National Museum 227:1-356 DOI 10.5479/si.03629236.227.1. 
753

754

755

756

757

758

759

760

761

762

763

764

765

766

767

768

769

770

771

772

773

774

775

776

777

778

779

780

781

782

783

784

785

Pisut DP, Pawlik JR. 2002. Anti-predatory chemical defenses of ascidians: secondary metabolites or inorganic acids? Journal of Experimental Marine Biology and Ecology 270:203-214 DOI 10.1016/S0022-0981(02)00023-0.

Read G, Fauchald K. 2016. World Polychaeta database accessed at http://www.marinespecies.org/polychaeta/aphia.php?p=taxdetails\&id=129262 on 2016-12-09.

Rivolta A, San Martín G, Sikorski A. 2016. Additions to the description, reproduction and systematic position of the enigmatic species Acritagasyllis longichaetosus Lucas, San Martín \&amp; Sikorski, 2010 (Annelida: Phyllodocida: Syllidae). Journal of the Marine Biological Association of the United Kingdom 96:1709-1716 DOI 10.1017/S0025315415002118.

San Martín G, López E. 2002. New species of Autolytus Grube, 1850, Paraprocerastea San Martín and Alós, 1989, and Sphaerosyllis Claparède, 1863 (Syllidae, Polychaeta) from the Iberian Peninsula. Sarsia 87:135-143 DOI 10.1080/003648202320205210.

Savigny J. 1816. Mémoires sur les animaux sans vertèbres. Paris: G. Dufour.

Say T. 1822. An account of some of the marine shells of the United States. Journal of the Academy of Natural Sciences of Philadelphia 2:221-248.

Sepúlveda RD, Rozbaczylo N, Ibáñez CM, Flores M, Cancino JM. 2015. Ascidianassociated polychaetes: ecological implications of aggregation size and tube-building chaetopterids on assemblage structure in the Southeastern Pacific Ocean. Marine Biodiversity 45:733-741 DOI 10.1007/s12526-014-0283-7.

Shenkar N. 2012. Ascidian (Chordata, Ascidiacea) diversity in the Red Sea. Marine Biodiversity 42:459-469 DOI 10.1007/s12526-012-0124-5.

Sinclair RJ, Hughes L. 2010. Leaf miners: the hidden herbivores. Austral Ecology 35:300-313 DOI 10.1111/j.1442-9993.2009.02039.x.

Skogsberg T, Vansell GH. 1928. Structure and behavior of the amphipod Polycheria osborni. Proceedings of the California Academy of Sciences 17:267-295.

Spooner GM, Wilson DP, Trebble N. 1957. Phylum Annelida. Plymouth Marine Fauna. Plymouth: Marine Biological Association U.K., 109-149.

Stock JH. 1967. Report on the Notodelphyidae (Copepoda, Cyclopoida) of the Israel South Red Sea Expedition. Israel South Red Sea Expedition, 1962, Reports 27:3-126.

Stoecker D. 1980. Chemical defenses of ascidians against predators. Ecology 61:1327-1334 DOI 10.2307/1939041.

Thiel M. 2000. Population and reproductive biology of two sibling amphipod species from ascidians and sponges. Marine Biology 137:661-674 DOI 10.1007/s002270000372. 
786 Utinomi H. 1956. On the so-called 'Umi-Utiwa' a peculiar flabellate gorgonacean, with notes on a syllidean polychaete commensal. Publications of the Seto Marine Biological Laboratory 5:243-250.

Vandepas LE, Oliveira LM, Lee SS, Hirose E, Rocha RM, Swalla BJ. 2015. Biogeography of Phallusia nigra: is it really black and white? The Biological Bulletin 228:52-64 DOI 10.1086/BBLv228n1p52.

Verrill AE. 1869. Synopsis of the polyps and corals of the North Pacific Exploring Expedition, under Commodore C. Ringgold and Capt. John Rodgers, USN, from 1853 to 1856. Collected by Dr. Wm. Stimpson, Naturalist to the Expedition. With descriptions of some additional species from the west coast of North America. Pt. 3: Madreporaria. Proceedings of the Essex Institute, 17-50.

White KM. 1949. Musculus lebourae, new species. Journal of Molluscan Studies 28:46-49 DOI 10.1093/oxfordjournals.mollus.a064557.

White KN. 2011. A taxonomic review of the Leucothoidae (Crustacea: Amphipoda). Zootaxa 3078:1-113.

Wright JD, Woodwick KH. 1977. A new species of Autolytus (Polychaeta: Syllidae) commensal on a Californian hydrocoral. Bulletin of the Southern California Academy of Sciences 76:42-48.

804 Zhan A, Briski E, Bock DG, Ghabooli S, MacIsaac HJ. 2015. Ascidians as models for studying invasion success. Marine Biology 162:0 DOI 10.1007/s00227-015-2734-5. 